\title{
REMOVAL OF REMAZOL RED DYE WITH LIVE CELL ASPERGILLUS TERREUS
}

\author{
Semra MALKOÇ* \\ Anadolu University, Applied Research Centre for Environmental Problems, Eskişehir
}

\begin{abstract}
Today a number of industries such as textile, paper and printing whose processes involve dyes discharge wastewater containing heavy pollution load directly into a receiving environment. Dyes, which are mutagenic and carcinogenic, spread across the receiving environment, threatening aquatic populations and human health severely. It is possible to reduce the contamination caused by these dyes by using biological methods. In this study, the decolorization technique is utilized for the treatment of textile industry wastewater. In order to achieve optimum efficiency, the optimal pH (4-5-6), temperature (30-40$\left.50{ }^{\circ} \mathrm{C}\right)$, biosorbent dose (0.025-0.05-0.1 g.) and stirring speed (75-100-125 rpm) were determined with the help of Taguchi $\mathrm{L}_{9}$ orthogonal array design. During the decolorization process, the sorption capacity of live cell Aspergillus terreus with Remazol Red (RR) dye measured $16.4(\mathrm{mg} / \mathrm{g})$ and the removal efficiency measured \%75.3 in conditions of $\mathrm{pH} 4.0$, temperature $30{ }^{\circ} \mathrm{C}$, biosorbent dose $0.1 \mathrm{~g}$. and the rotational speed $125 \mathrm{rpm}$ on $5^{\text {th }}$ days.
\end{abstract}

Keywords: Aspergillus terreus, Decolorization, Remazol Red, Taguchi

\section{INTRODUCTION}

Since ancient times, dyes play an important role in human history. Considering the amount of excess dye after production and during use, the environmental importance of colored dye is obvious. The presence of color and organic waste in dyes is a serious problem and need to be eliminated before discharging. Since they consist of various organic substances, dissolved salts, and a high amount of dyes, they are blurred and when discharged at various $\mathrm{pH}$ levels, they need to be trested [1]. The realization of photosynthesis by blocking the sunlight are significantly affected. Decolorization of dyes formed to dissolve oxygen concentration is very important. Aromatic stable complex molecular structures and synthetic origin is difficult to dye in biodegradation. Pharmaceutical, oil, textile, paper, printing, steel, coke, waste water in many industries, such as pesticides and paint contain high amounts of organic chemicals. These are dyes and are an important group of organic pollutants [2].

The most widely commercially used are azo dyes. Azo dye substances cannot be broken up easily and constitute $60-70 \%$ of textile waste. The dissolution of these dyes in solution is difficult to treatment with conventional treat methods. The main reasons for the commercial use is the low cost and simple use. Even at low concentrations, they change the aesthetic property by lowering the solubility of the water. Resolution is affected by a decrease in photosynthetic activity; life in the aquatic environment is adversely affected [3].The dying process is used to color cloth and the characterization is very difficult because of the difference in the chemical composition of the dyes. Nowadays, decolorization is mostly performed through physical and chemical procedures. However, the cost of these procedures is very high and there are problems in the removal of concentrated mud. Therefore, the use of bioremediation over physical and chemical procedures is a more efficient and economical way to remove colorants in wastewater. The ability of bacteria [4], fungi [5], and the other biological materials to decolorization dye especially Remozal Red dye has been successfully investigated [6]. Determination of optimum process conditions ( $\mathrm{pH}$ of solution, biosorbent dosage, agitation period, temperature etc.) is also mandatory to achieve maximum decolorization capacity [7]. 
The Taguchi method was designed by Dr. Genich Taguchi in the 1950s. The Taguchi method uses different parameters is a useful method for determining the best combination of different levels. Each parameter requires a lot of experimental work for all combinations with each level. Thus, using the Taguchi method it is possible to reach a result with fewer experimental studies [8-11].

700.000 tons of paint is used per year in the textile industry and this is show that is one of the most polluting industries. Discharging the water of industrial treatment facilities and $10 \%$ of dyes results in the decrease of dissolved oxygen, which in turn affects the health of the living population in these waters. Dying material not only harm the water ecosystem but also the health of humans and therefore, it is vital to treat waste water. Biological treatment methods, in addition to physical and chemical methods are both more environmentally friendly and more economical.

The main purpose of the this study is to screen and then invesitigate the adsorption abilities of the Aspergillus terreus isolated from automotive industry wastewater, as a novel adsorbent, for the elimination of Remozal Red dye in a aqueous solution. The Taguchi design method was used to optimize decolorization. Tacughi's $\mathrm{L}_{9}$ experimental design was created and impacts of process variables $(\mathrm{pH}$, biosorbent dose, temperature and stirring speed) on decolorization capacity were analyzed. Within the paper, experimental data were also applied to the removal efficiency and decolorization capacity.

\section{MATERIALS AND METHOD}

\subsection{Preparation of Biosorbent}

The fungi was isolated from automotive industry wastewater. The pure culture was maintained on the potato dextrose agar at $4{ }^{\circ} \mathrm{C}$. Aspergillusterreus was grown in the potato dextrose broth for 7 days. The biosorbent dose that adequate for experiments was collected by filtration through Whatmann filter paper No.1 and was thoroughly washed with distilled deionized water to remove residual growth medium. The washed biosorbent dose (live biosorbent dose) was used immediately thereafter and then stored in a refrigerator for experiments.

\subsection{Preparation of Dye Solution}

The textile reactive (Figure 1) was used in the experiment. Molar weight of Remazol Red (RR) is 875 $\mathrm{g} / \mathrm{mol}$. Remazol Red (RR) stock solution (1g/L) was prepared by dissolving an appropriate weight amount of RR in $1 \mathrm{~L}$ ultrapure water. The experimental solutions of desired initial concentrations were by dilution of RR stock solution with ultrapure water. The maximum absorbance wavelength ( $\lambda \max )$ of RR was found to be $543 \mathrm{~nm}$ using UV-Visible spectrometer (Hach, model DR 5000).

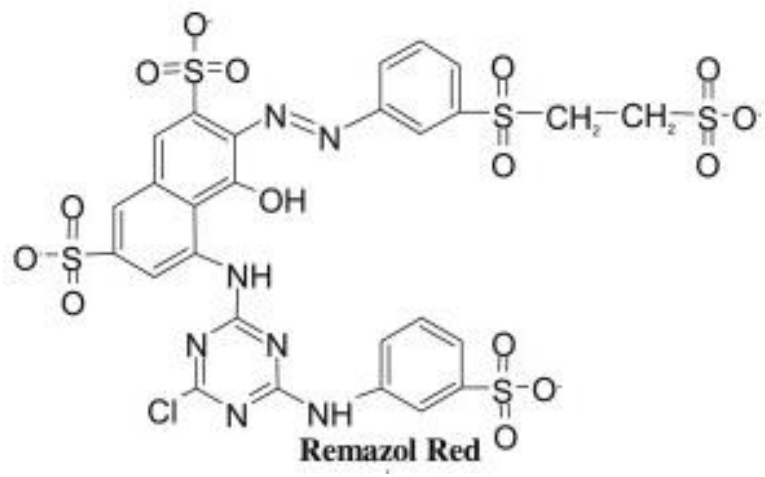

Figure 1. Structure of Remazol Red. 


\subsection{Batch Decolorization Experiments}

In order to view the decolorization performance, experiments were carried out in 100-mL erlenmeyer flasks containing $50 \mathrm{~mL}$ of $\mathrm{RR}$ solution $(50 \mathrm{mg} / \mathrm{L})$, and biosorbent dose, $\mathrm{pH}$ and temperature and stirring speed. The flasks were shaken in an orbital shaker for $24 \mathrm{~h}$. Controls without Aspergillusterreus were incubated under the same condition. All of the experiments were carried out in triplicate. The degree of decolorizaiton of the RR was measured with UV- Visible spectrometer (Hach, model DR 5000). The amount of RR adsorbed per unit weight of Aspergillusterreus biosorbent dose at equilibrium, $q e(\mathrm{mg} / \mathrm{g})$, and percentage dye removal $(R \%)$, were calculated with the following equations:

$$
\begin{aligned}
& q e=\left(\mathrm{C}_{0}-\mathrm{C}_{\mathrm{e}}\right) / \mathrm{X} \\
& R \%=\left(\mathrm{C}_{0}-\mathrm{C}_{\mathrm{e}}\right) / \mathrm{C}_{0} \times 100
\end{aligned}
$$

where $\mathrm{C}_{0}(\mathrm{mg} / \mathrm{L}), \mathrm{C}_{\mathrm{e}}(\mathrm{mg} / \mathrm{L})$ and $X(\mathrm{~g} / \mathrm{L})$ are the initial RR concentration, the RR concentration at equilibrium and the sorbent concentration in the solution, respectively.

\subsection{Design of Experiments Process}

Taguchi $\mathrm{L}_{9}$ orthogonal array design is to properly analyze the targeted or investigated results and the deviations from these results; and to effectively plan the experimental group [12]. For this purpose, various experimental design matrices were created. Tacughi $\mathrm{L}_{9}$ experimental design is one of them. As known $\mathrm{pH}$, biosorbent dose, concentration, rotational speed and temperature are among the most important factors in adsorption processes. Three levels were selected for each of the studied factors (pH:4.0, 5.0, 6.0, biosorbent dose: $0.025,0.05,0.1 \mathrm{~g}$, temperature: $30,40,50{ }^{\circ} \mathrm{C}$, stirring speed: 75 , $100,125 \mathrm{rpm})$. The ranges and the levels of the variables studied in this research are shown in Table 1.

Table 1. Factors and levels used in the Taguchi's $\mathrm{L}_{9}$ experimental design

\begin{tabular}{lccc}
\hline Independent variable & \multicolumn{3}{c}{ Levels } \\
\hline $\mathrm{pH}$ & 4 & 5 & 6 \\
Biosorbent dose $(\mathrm{g})$ & 0.025 & 0.05 & 0.1 \\
Temperature & 30 & 40 & 50 \\
Stirring speed & 75 & 100 & 125 \\
\hline
\end{tabular}

Optimization process and required calculations were performed by using Minitab 17 software package and Microsoft Excel 2010.

\section{RESULTS AND DISCUSSION}

\subsection{Determination of Optimal Conditions using Taguchi L Experimental Design}

The Taguchi method was used to determine the optimal conditions and to obsorve the parameters having the most effective on the RR removal. In the Taguchi method, the terms 'signal' and 'noise' represent the desirable and undesirable values for the output characteristic, respectively. Taguchi method uses the Signal/Noise $(\mathrm{S} / \mathrm{N})$ ratio to measure the quality characteristic deviating from the desired value. The $\mathrm{S} / \mathrm{N}$ ratios are different according to the type of characteristic. Figure 2. shows the Signal/Noise $(\mathrm{S} / \mathrm{N})$ response graph for decolorization of RR solution. Based on the Signal/Noise $(\mathrm{S} / \mathrm{N})$ ratio, the optimal parameters for dye removal are $\mathrm{pH}$ at 4 , temperature at $30^{\circ} \mathrm{C}$, biosorbent dose $0.1 \mathrm{~g}$., stirring speed $125 \mathrm{rpm}$ (Table 2). Finally, in this condition $75.3 \%$ dye removal can be obtained. 
Table 2. Optimal experimental conditions

\begin{tabular}{cc}
\hline Parameters & Data \\
\hline Biosorbent dose & $0.1 \mathrm{~g}$ \\
$\mathrm{pH}$ & 4 \\
Temperature & $30^{\circ} \mathrm{C}$ \\
Stirring speeed & $125 \mathrm{rpm}$ \\
\hline
\end{tabular}

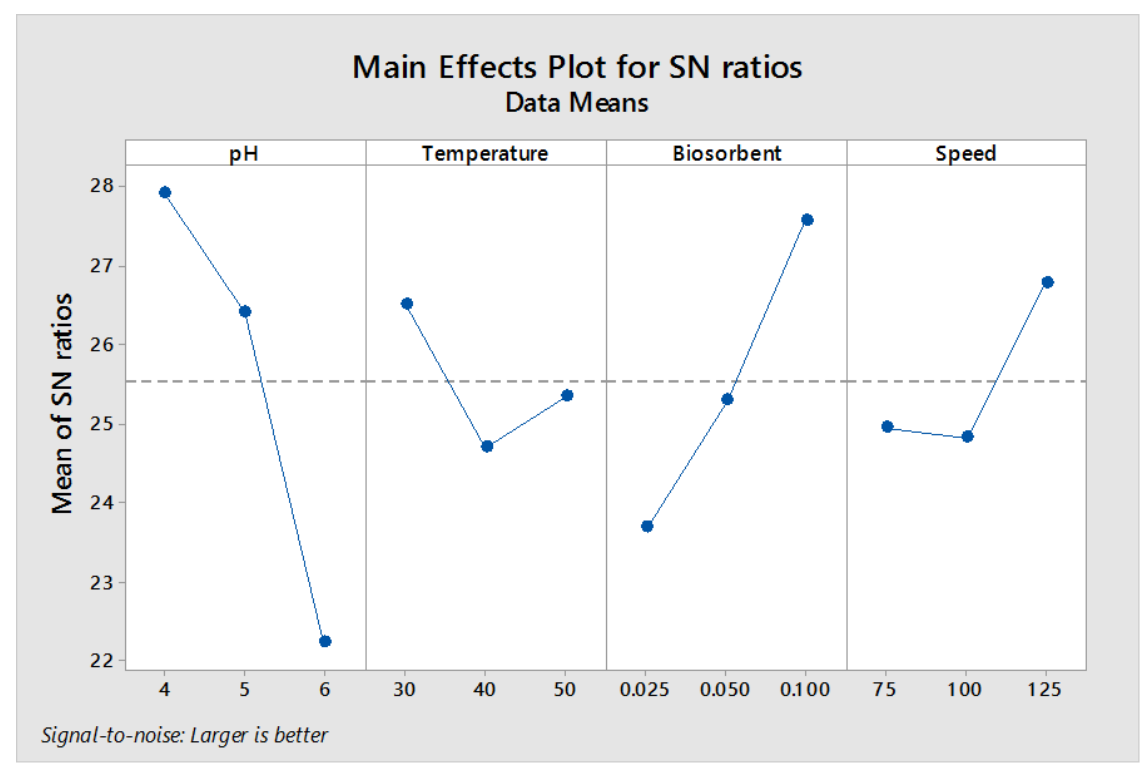

Figure 2. Taguchi L9 experimental design factors interact graph

\subsection{Effect of Contact Time}

For the decolorizaiton processes, experiments were carried out for different contact times with a fixed biosorbent dose 0.1 g., stirring speed $125 \mathrm{rpm}$, at $\mathrm{pH} 4$, and $30^{\circ} \mathrm{C}$. Decolorizaiton of Remazol Red (RR) with Asperdgillus terreus showed that absorbance ratio was highest $(75.3 \%)$ at the $5^{\text {th }}$ day but, thendecrease rapidly (Figure 3).

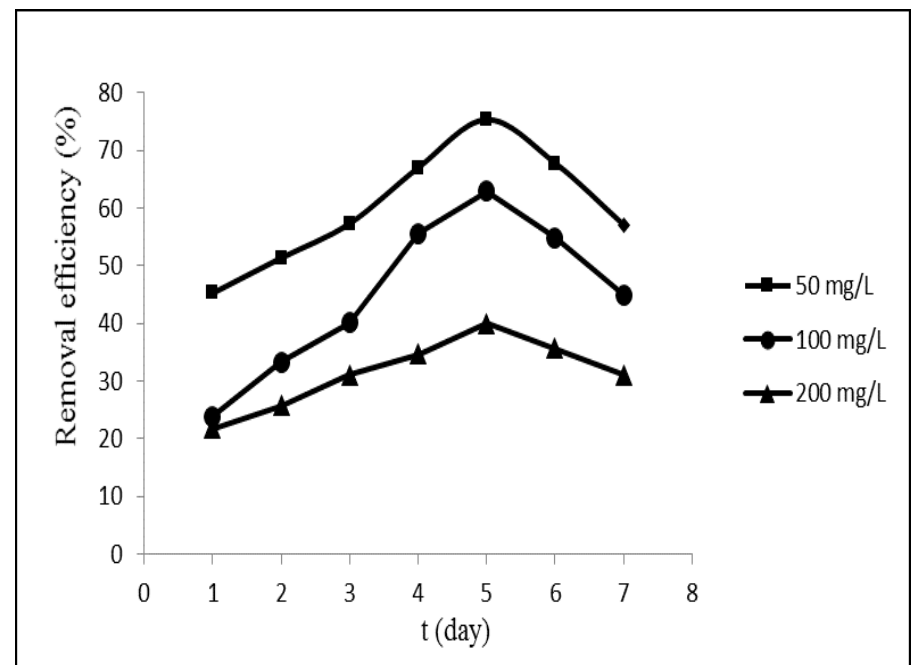

Figure 3. Effect of contact time on RR decolorization onto Aspergillus terreus at three different initial RR concentrations (biosorbent dose $=0.1 \mathrm{~g} ., \mathrm{pH}=4$, stirring speed $=125 \mathrm{rpm}$ ) 


\subsection{Effect of Dye Concentration and Temperature}

Temperature is one of the most effective parameters in the growing microorganisms. Even if the optimum conditions are determined by experimentation with the experiment design, all variables except temperature should be kept constant and the effect of temperature change should be observed. Decolorization experiments were carried out at three initial Remazol Red (RR) concentrations (50$100-200 \mathrm{mg} / \mathrm{L}$ ) and at temperature $\left(30-40-50^{\circ} \mathrm{C}\right)$. Removal efficiency of RR with Aspergillus terreus decreased with increased initial concentration and temperature (Figure 4-Figure 9).

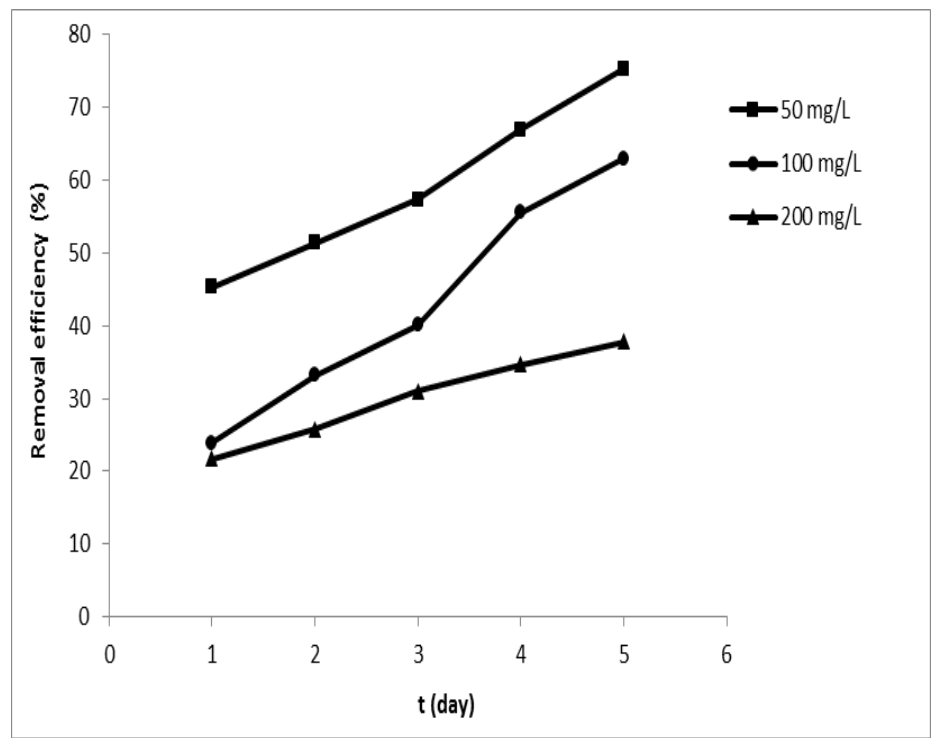

Figure 4. Influence of initial dye concentration and temperature on removal efficiency ( $\mathrm{T}=30^{\circ} \mathrm{C}$, biosorbent dose $=0.1$ g., $\mathrm{pH}=4$, stirring speed $=125 \mathrm{rpm}$ )

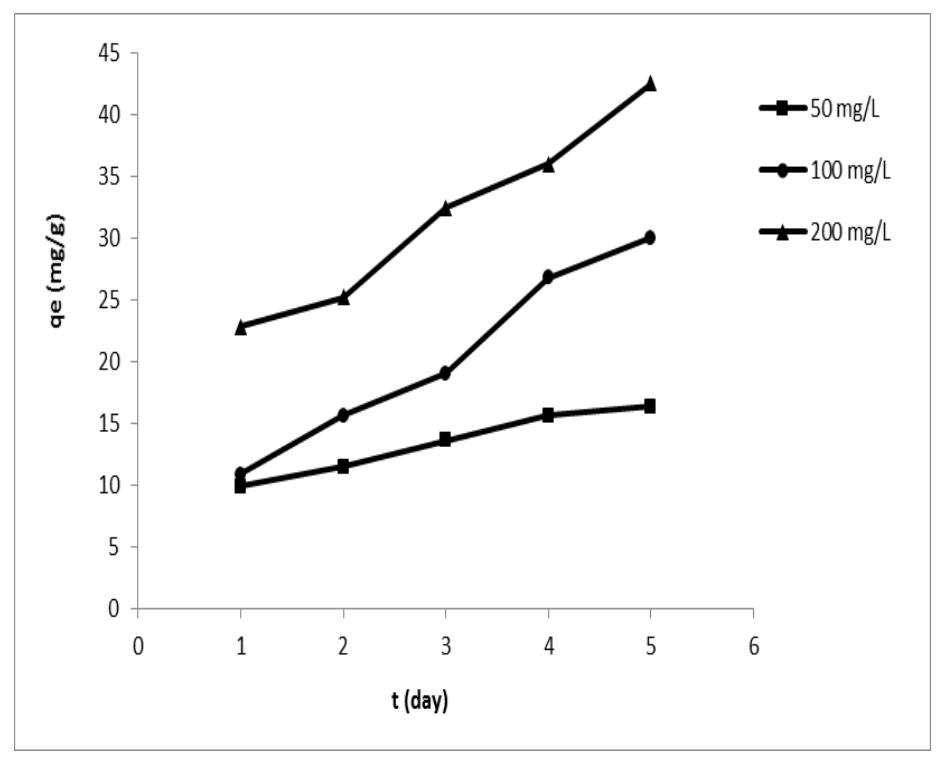

Figure 5. Influence of initial dye concentration and temperature on decolorization capacity $\left(\mathrm{T}=30{ }^{\circ} \mathrm{C}\right.$, biosorbent dose $=0.1 \mathrm{~g} ., \mathrm{pH}=4$, stirring speed $=125 \mathrm{rpm}$ ) 
Malkoç / Anadolu Univ. J. of Sci. and Technology A-Appl. Sci. and Eng. 18 (3) - 2017

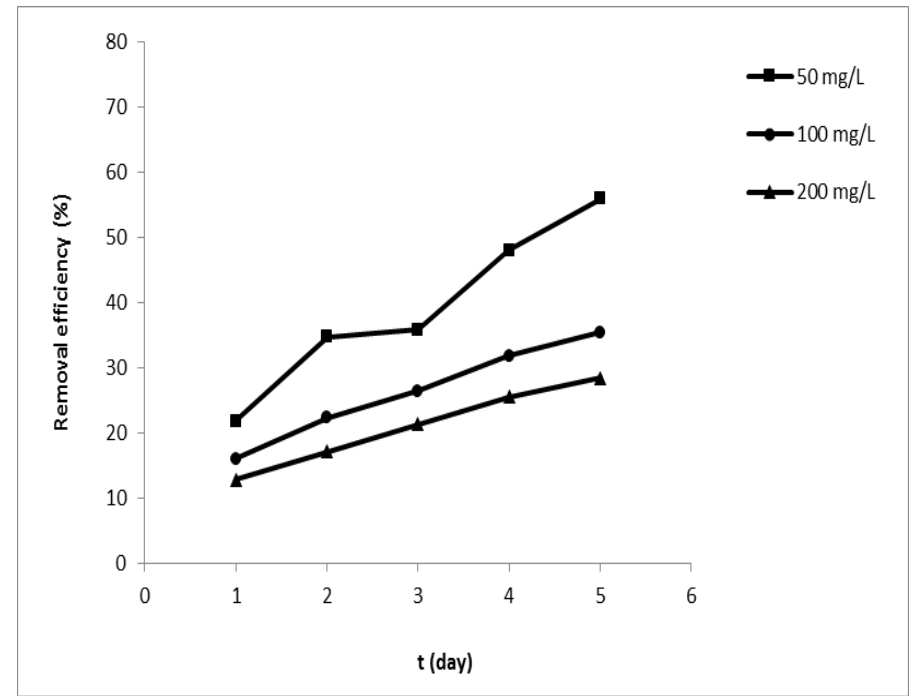

Figure 6. Influence of initial dye concentration and temperature on removal efficiency $\left(\mathrm{T}=40^{\circ} \mathrm{C}\right.$, biosorbent dose $=0.1$ g., $\mathrm{pH}=4$, stirring speed=125 rpm)

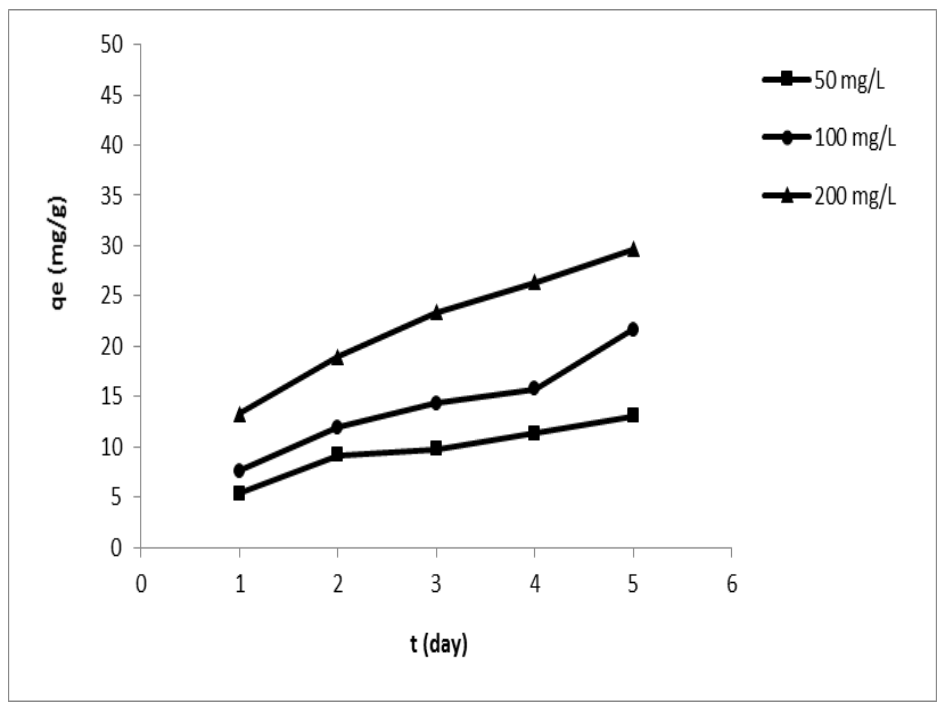

Figure 7. Influence of initial dye concentration and temperature on decolorization capacity $\left(\mathrm{T}=40{ }^{\circ} \mathrm{C}\right.$, biosorbent dose $=0.1 \mathrm{~g}$., $\mathrm{pH}=4$, stirring speed $=125 \mathrm{rpm}$ ) 


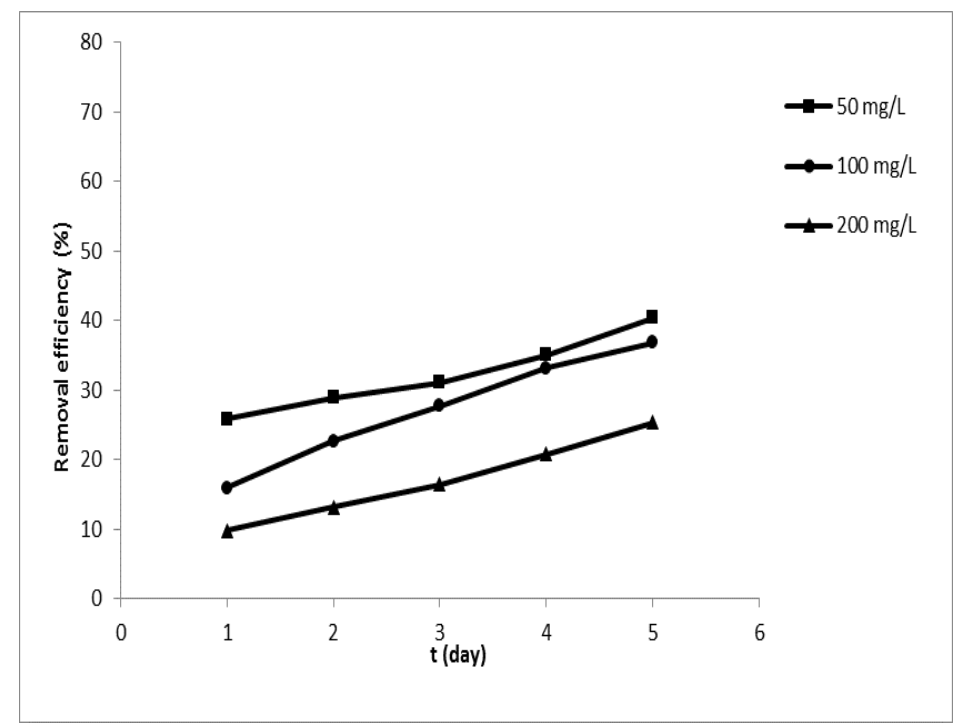

Figure 8. Influence of initial dye concentration and temperature on removal efficiency ( $\mathrm{T}=50{ }^{\circ} \mathrm{C}$, biosorbent dose $=0.1$ g., $\mathrm{pH}=4$, stirring speed $=125 \mathrm{rpm}$ )

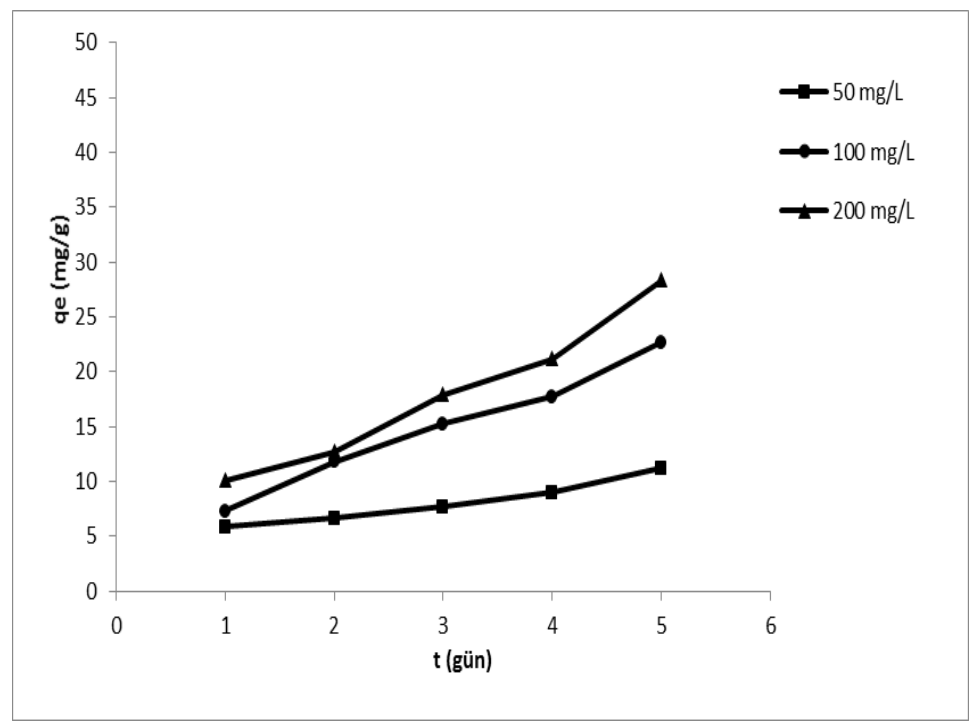

Figure 9. Influence of initial dye concentration and temperature on decolorization capacity $\left(\mathrm{T}=50{ }^{\circ} \mathrm{C}\right.$, biosorbent dose $=0.1 \mathrm{~g} ., \mathrm{pH}=4$, stirring speed $=125 \mathrm{rpm}$ )

The Taguchi $\mathrm{L}_{9}$ experimental design applied in this research was a valuable tool to optimize the Remozal Red (RR) adsorption process using Aspergillus terreus. The results obtained show that the decolorization process becomes slower with higher dye concentrations and temperature when using initial concentrations of 50,100, and $200 \mathrm{mg} / \mathrm{L}$. Lysinibacillus sp. have shown $87 \%$ decolorization [13], the alligator weed Aspergillus philoxeroides could completely decolorize Remazol Red (RR) dye [14], Aster amellus Linn. decolorized a sulfonated azo dye Remazol Red (RR) 96\% [15] different operational conditions. 


\section{CONCLUSION}

This study demonstrates the usefulness of Taguchi $\mathrm{L}_{9}$ experimental design to model remozal red decolorization from aqueous solutions by Aspergillus terreus biosorbent dose. The most significant factors affecting remozal red removal efficiency were $\mathrm{pH}$, biosorbent dose, temperature and stirring speed. The fungal strain proved to be candidate for removal of Remazol Red (RR) within pH 4.0, $0.1 \mathrm{~g}$ of biosorbent dose, $30^{\circ} \mathrm{C}$ and $125 \mathrm{rpm}$. At these conditions, remozal red removal efficiency was 75.3 $\%$ and decolorization capacity was $16.4 \mathrm{mg} / \mathrm{g}$. Further studies to opimize conditions of settling characteristics of other textile dyes and fungi.

\section{ACKNOWLEDGEMENTS}

This work was financially supported by the Unit of the Scientific Research Projects of Anadolu University under grant no. 1505F294.

\section{REFERENCES}

[1] Priyaragini S, Swetha D, Kumar G, Bhaskara Rao KV. Evaluating the effectiveness of marine actinobacterial extract and its mediated titanium dioxide nanoparticles in the degradation of azo dyes. J Environ Sci 2014; 26:775-782.

[2] Chakraborty S, Basak B, Dutta S, Bhunia B, Dey A. Decolorization and biodegradation of congo red dye by a novel white rot fungus Alternaria alternata CMERI F6. Bioresource Technol 2013; 147:662-666.

[3] Almeida EJR, Corso CR. Comparative study of toxicity of azo dye procion red MX-5B following decolorization and biodegradation treatments with the fungi Aspergillus niger and Aspergillus terreus. Chemosphere, 2014;112:317-222.

[4] Lu L, Zhao M, Wang TN, Zhao LY, Du MH, Li TL, Li DB. Characterization and dye decolorization ability of an alkaline resistant and organic solvents tolerant laccase from Bacillus licheniformis LS04. Bioresource Technol 2012; 115: 35-40.

[5] Sivasamy A, Sundarabal N. Decolorization of an azo dye by Aspergillus niger and Trichoderma sp. Fungal Biosorbent dosees. Curr Microbiol 2011; 62:351-357.

[6] Armagan B, Toprak F. Using pistachio shell for Remazol Red removal from aqueous solutions: equilibrium, kinetics and thermodynamics. Desalin Water Treat 2015; 56:136-145.

[7] Cerino-Córdova FJ, García-León AM, Soto-Regalado E, Sánchez-González MN, Lozano-Ramírez T, García-Avalos BC, Loredo-Medrano JA. Experimental design for the optimization of copper decolorization from aqueous solution by Aspergillus terreus. J Environ Manage 2012; 95:577-582.

[8] Ozdemir U, Ozbay B, Ozbay I, Veli S. Application of Taguchi L32 orthogonal array design to optimize copper decolorization by using Spaghnum moss. Ecotox Environ Safe 2014; 107:229-235.

[9] Gençosman BÇ, Orbak AY, Orbak, İ. Deneysel tasarım ile sulu çözeltilerden metal ayrışımına etki eden faktörlerin optimizasyonu. Uludağ Üniversitesi Mühendislik Fakültesi Dergisi, 2015; 20: 3949.

[10] Ozbay N, Yargic, AS. Factorial experimental design for Remazol Yellow dye sorption using apple pulp/apple pulp carbonetitanium dioxide co-sorbent. J Clean Prod 2015; 100:333-343. 
Malkoç / Anadolu Univ. J. of Sci. and Technology A-Appl. Sci. and Eng. 18 (3) - 2017

[11] Chen C-H, Huang C-Y. Improve electromagnetic interference of electronic products with Taguchi parametric design. Measurement 2017;102:200-207.

[12] Daneshvar N, Khataee AR, Rasoulifard MH, Pourhassan M. Biodegradation of dye solution containing Malachite Green: Optimization of effective parameters using Taguchi method. J Hazard Mater 2007; 143:214-219.

[13] Saratale RG, Gandhi SS, Purankar MV, Kurade MB, Govindwar SP, Oh SE, Saratale GD. Decolorization and detoxification of sulfonated azo dye C.I. Remazol red and textile effluent by isolated Lysinibacillus sp. RGS. J Biosci and Bioeng 2013; 115:658-667.

[14] Rane NR, Chandanshive VV, Watharkar AD, Khandare RV, Patil TS, Pawar PK, Govindwar SP. Phytoremediation of sulfonated Remazol Red dye and textile effluents by Alternanthera philoxeroides: An anatomical, enzymatic and pilot scale study. Water Res 2015; 83:271-281.

[15] Khandare RV, Kabra AN, Tamboli DP, Govindwar SP. The role of Aster amellus Linn. in the degradation of a sulfonated azo dye remazol red: a phytoremediation strategy. Chemosphere 2011; 82:1147-1154. 